\title{
Fractionation and Characterization of Brewers' Spent Grain Protein Hydrolysates
}

\author{
Inge Celus, ${ }^{*}$ Kristof Brijs, and Jan A. Delcour \\ Laboratory of Food Chemistry and Biochemistry and Leuven Food Science and Nutrition Research \\ Centre (LFoRCe), Katholieke Universiteit Leuven, Kasteelpark Arenberg 20, B-3001 Leuven, Belgium
}

\begin{abstract}
Protein hydrolysates with a low and high degree of hydrolysis were enzymatically produced from brewers' spent grain (BSG), the insoluble residue of barley malt resulting from the manufacture of wort in the production of beer. To that end, BSG protein concentrate (BPC), prepared by alkaline extraction of BSG and subsequent acid precipitation, was enzymatically hydrolyzed with Alcalase during both 1.7 and $120 \mathrm{~min}$. Because these hydrolysates contained many different peptides, fractionation of the hydrolysates with graded ammonium sulfate or ethanol precipitation was performed to obtain fractions homogeneous in terms of molecular weight (MW) and hydrophobicity. The emulsifying and foaming capacities of the resultant fractions were determined. MW distributions and surface hydrophobicities of fractions with protein contents exceeding $75 \%$ were investigated to determine relationships between technofunctional and physicochemical properties. It was found that the emulsifying and foaming properties are determined by different physicochemical properties of the proteins or peptides. Neither MW nor hydrophobicity alone determines the emulsifying and foaming properties of protein hydrolysates. BSG protein hydrolysates with good emulsifying properties contained less than $40 \%$ of fragments with MW exceeding 14500 . Moreover, these hydrolysates had a high surface hydrophobicity. BSG protein hydrolysates with good foaming properties contained less than $10 \%$ of material with MW lower than 1700 . Hydrolysates with good foaming properties showed low surface hydrophobicities, except for protein hydrolysates with higher levels of protein fragments with MW exceeding 14500 than of such fragments with MW in a 1700-14500 range.
\end{abstract}

KEYWORDS: Brewers' spent grain; proteolysis; hydrolysates; fractionation; technofunctional properties

\section{INTRODUCTION}

Brewers' spent grain (BSG), the residue left after separation of wort during the brewing process, is rich in protein and fiber. However, to date, its use has mainly been limited to animal feeding. To increase the potential application of such insoluble proteins, they can be hydrolyzed. We reported earlier (1) that enzymatic hydrolysis of BSG proteins improves emulsifying and foam-forming properties. Because proteins and peptides do not dissolve in oil, they can only stabilize oil-in-water emulsions (2). The physicochemical characterization of the hydrolysates showed the importance of the presence of protein fragments with relatively high molecular weight (MW) (exceeding 14 500) and high surface hydrophobicity for favorable technofunctional properties. The type of enzyme used also had a large impact on the obtained technofunctional properties (1). However, these hydrolysates consisted of heterogeneous mixtures of low MW as well as high MW peptides with varying hydrophobicities. We set out to fractionate these hydrolysates to determine relationships between their physicochemical and technofunctional properties.

*To whom correspondence should be addressed. Telephone: +3216321634. Fax: +32-16321997. E-mail: inge.celus@ biw.kuleuven.be.
Ultrafiltration [100000, 50000, and $20000 \mathrm{MW}$ cutoff (MWCO) (3) and $30000 \mathrm{MWCO}$ (4)] of gluten hydrolysates indicated that their contribution to foam stability (FS) decreases as the MW of hydrolysate fractions decreases. It is clear that a minimum three-dimensional structure has to be retained if the resulting hydrolysates are to have foaming and emulsifying properties. Polypeptides with low MW are unable to form stable protein films at the oil-water or air-water interfaces $(5,6)$. According to Wang et al. (3), emulsifying and foaming capacities are associated with surface hydrophobicities. Determination of the emulsifying properties of gluten hydrolysates showed that the most hydrophobic peptides were adsorbed at the interfacial layer, while the hydrophilic peptides were present in the aqueous phase (7). Gluten hydrolysates, prepared by limited enzymatic hydrolysis with chymotrypsin and subsequent ultrafiltration (150000 and $50000 \mathrm{MWCO}$ ), resulted in retentates, which contained peptides that were both hydrophobic and positively charged, whereas the permeates contained hydrophilic and neutral peptides. This resulted in opposite technofunctional properties, probably because amphipathicity of peptides is a major factor for their ability to stabilize interfaces. Permeates had foaming capacity at $\mathrm{pH} 6.5$ but neither foam-stabilizing nor emulsifying properties. The retentates showed better emulsifying and foaming properties at 
pH 4.0 and 6.5 than the hydrolysates $(8,9)$. Also, the foaming properties of gluten protein hydrolysates depend less upon their solubility than their emulsifying properties (10).

The optimum peptide size of hydrolysates generated from soy proteins for emulsifying and foaming properties generally lies between 15 and 35 amino acids (11). Proteolysis of SPI followed by ultrafiltration $(100000,50000$, and $20000 \mathrm{MWCO})$ results in permeate peptides with higher emulsifying capacity but lower surface hydrophobicity than those of the peptides in the retentate and the starting material hydrolysates (12). However, a high correlation between surface hydrophobicity and emulsifying activity has also been reported $(13,14)$. Hence, solubility and MW rather than surface hydrophobicity might be the major factors conferring high emulsifying activity to the small peptides of the permeates (12). Furthermore, protein solubility has a greater impact on the ability of soy protein hydrolysates to form and stabilize foams than surface hydrophobicity (15).

Enzymatic hydrolysis of maize gluten followed by ultrafiltration resulted in a fraction of MW < 5000 with higher emulsifying activity and emulsion stability (ES) than those of the other fractions. Fractions of MW $<5000$ and MW > 10000 showed poor foaming capacity at $\mathrm{pH}$ values below 6.0. The FS of these fractions increased with $\mathrm{pH}$, but that of the fraction with intermediate MW (5000-10000) decreased with increasing $\mathrm{pH}(16)$. Quinoa protein concentrate had higher emulsifying capacities than the resulting hydrolysate. This could probably be related to the high degree of hydrolysis (DH) $(48 \%)$. However, the hydrolysate had better ES than the protein concentrate. Despite the higher foaming capacity of hydrolysate than that of the protein concentrate, the protein concentrate showed higher FS. Ultrafiltration (10000 and $5000 \mathrm{MWCO})$ of quinoa protein hydrolysate led to permeates that had lower emulsifying and foaming properties than the protein hydrolysate (17).

To identify structure-function relationships for $\beta$-casein hydrolysates, such hydrolysates were prepared with plasmin. They were further fractionated by ultrafiltration [5000 MW cutoff (MWCO)] and selective precipitation with acid and/or ethanol $(\mathrm{EtOH})$, which resulted in several peptide fractions. The hydrophilic peptides had poor technofunctional properties. The hydrophobic peptides showed interesting foam-forming properties, whereas the amphipathic peptides exhibited good emulsionforming properties $(18,19)$. Electrostatic repulsion between emulsion droplets caused by the amphipathic $\beta$-casein peptides is probably the main reason for their emulsion-stabilizing properties (20). The positive effect of peptides of MW exceeding 2000 on ES was demonstrated with different fractions of casein and whey protein hydrolysates (21). Foam formation by casein hydrolysates is independent of the MW of the peptides, whereas foam-forming whey protein hydrolysates seem to contain a percentage of peptides larger than 3000 contributing to this property. The stability of casein hydrolysate foams has been specifically related to peptides with MW exceeding 7000. For foam formation, the presence of amphiphilic peptides might be the most important factor, whereas, for FS, the presence of peptides of relatively high MW seems to be crucial (22).

As a sequel to a profound characterization of the hydrolysates resulting from enzymatic hydrolysis of BSG proteins (1), the aim of the present work was to obtain homogeneous fractions in terms of MW and hydrophobicity by fractionating the BSG protein hydrolysates by selective precipitation with EtOH and ammonium sulfate (AS). To the best of our knowledge, fractionation of plant protein hydrolysates with graded AS or EtOH precipitation has not been described in the literature. The emulsifying and foaming properties of the resultant fractions were examined. The MW distributions and surface hydrophobicities of fractions with protein contents exceeding $75 \%$ were further studied. Finally, the relationships between physicochemical and technofunctional properties of BSG protein hydrolysates were investigated.

\section{MATERIALS AND METHODS}

Materials. BSG [25\% protein on a dry basis (db)] was from an allmalt mash pilot scale brewery experiment described earlier by Celus et al. (23). Bacillus licheniformis Alcalase was obtained from Novozymes (Bagsvaerd, Denmark). The main enzyme component of Alcalase is Subtilisin A (Subtilisin Carlsberg). Alcalase (7.8\% protein) is a commercial enzyme preparation with high peptidase and limited $\alpha$-amylase activities. The peptidase activity determined with hemoglobin as a substrate under the experimental conditions described by Brijs et al. (24) was $0.32 \mathrm{AU} / \mathrm{g}$. Hyfoama 77 and Versa Whip 510 were enzymatically produced hydrolysates from wheat and soybean protein, respectively, and were from Quest International (Naarden, The Netherlands). SE70M, an enzymatically produced soybean protein hydrolysate, was from DMV International (Veghel, The Netherlands). Denatured ethanol (95\%, further referred to as EtOH) was from Brenntag (Mülheim/Ruhr, Germany). All other reagents and chemicals were purchased from Sigma-Aldrich (Bornem, Belgium) and were of analytical grade unless specified otherwise.

Enzymatic Hydrolysis of BSG Protein Concentrate (BPC). BPC, prepared by alkaline extraction of BSG followed by acid precipitation (1), was incubated with Alcalase. This enzyme was selected on the basis of the results obtained in earlier work (1). BPC was hydrolyzed for 1.7 and $120 \mathrm{~min}$, respectively, to obtain hydrolysates with low and high DH, i.e., the ratio of the number of peptide bonds hydrolyzed to the total number of peptide bonds per unit weight present in BPC protein. Because high amounts of hydrolyzed proteins were needed for further experimental work, enzymatic hydrolysis of BPC [150 g (db)] was performed in a water bath (further referred to as "large scale"). A $6.0 \%$ (w/v on protein basis) aqueous dispersion of BPC was hydrolyzed for 1.7 and $120 \mathrm{~min}$ at $\mathrm{pH} 9.0$ and $60{ }^{\circ} \mathrm{C}$ with Alcalase $[2.5 \%$ enzyme preparation/substrate ratio $(\mathrm{w} / \mathrm{w}$ of protein)]. During the $120 \mathrm{~min}$ hydrolysis, the $\mathrm{pH}$ was adjusted by manual addition of $1.0 \mathrm{~mol} / \mathrm{L} \mathrm{NaOH}$ in $30 \mathrm{~min}$ time intervals. After the reaction, the mixture was adjusted to $\mathrm{pH} 6.0$ with $2.0 \mathrm{~mol} / \mathrm{L}$ citric acid and heated in a water bath at $95^{\circ} \mathrm{C}$ for $10 \mathrm{~min}$ to inactivate the enzyme. Aliquots $(50 \mu \mathrm{L})$ of the total hydrolysate obtained after enzymatic hydrolysis were withdrawn for colorimetric determination of DH with $o$-phthaldialdehyde (OPA) (1). The remaining mixtures were centrifuged ( $5000 \mathrm{~g}$ for $20 \mathrm{~min}$ at $4{ }^{\circ} \mathrm{C}$ ), and the resulting supernatants were freeze-dried. Sample codes consist of three characters representing the enzyme Alcalase (Alc) and two digits encoding the $\mathrm{DH}$.

Fractionation of BPC Hydrolysates by Ammonium Sulfate Precipitation. On the basis of the outcome of initial experiments, a $3.0 \%(\mathrm{w} / \mathrm{v})$ aqueous dispersion of the hydrolysates was separated into three fractions by graded AS precipitation. Aliquots of AS were added under continuous stirring to a final concentration of $40 \%(\mathrm{w} / \mathrm{v})$. The mixtures were then kept overnight at $4{ }^{\circ} \mathrm{C}$. Precipitated material was recovered by centrifugation ( $10000 \mathrm{~g}$ for $10 \mathrm{~min}$ at $4{ }^{\circ} \mathrm{C}$ ), dispersed in deionized water, dialyzed against deionized water using 6000-8000 MWCO regenerated cellulose dialysis membranes (Spectra/Por, VWR International, Haasrode, Belgium), and freeze-dried to obtain fraction $\mathrm{AS}_{0-40}$. The AS concentration of the supernatant was further increased to $60 \%(\mathrm{w} / \mathrm{v})$, and the precipitated fraction, referred to as fraction $\mathrm{AS}_{40-60}$, was recovered as described above. The remaining fraction was dialyzed against deionized water (6000-8000 MWCO), freeze-dried, and recovered as fraction $\mathrm{AS}_{60+}$

Fractionation of BPC Hydrolysates by Ethanol Precipitation. On the basis of the outcome of initial experiments, the hydrolysates $(6.0 \%$, $\mathrm{w} / \mathrm{v}$ ) were separated into four fractions by graded EtOH precipitation. Aliquots of $\mathrm{EtOH}$ were added under continuous stirring to a final concentration of $70 \%(\mathrm{v} / \mathrm{v})$. The mixtures were then kept overnight at $4{ }^{\circ} \mathrm{C}$. Precipitated material was recovered by centrifugation $(10000 \mathrm{~g}$ for $10 \mathrm{~min}$ at $4{ }^{\circ} \mathrm{C}$ ), dispersed in deionized water, and freeze-dried to obtain fraction $\mathrm{EtOH}_{0-70}$. The EtOH concentration of the supernatant was subsequently increased to $80 \%(\mathrm{v} / \mathrm{v})$ and, in a third step, to $90 \%$ $(\mathrm{v} / \mathrm{v})$. The corresponding precipitated fractions, referred to as fractions $\mathrm{EtOH}_{70-80}$ and $\mathrm{EtOH}_{80-90}$, were recovered as described above. EtOH was 
removed from the remaining supernatant by rotary evaporation. The resulting fraction was freeze-dried and recovered as fraction $\mathrm{EtOH}_{90+}$.

Partial Chemical Composition of Hydrolysates and Their Fractions. Protein contents of the hydrolysates were determined using the Dumas combustion method, an adaptation of the Association of Official Analytical Chemists (AOAC) official method (25) to an automated Dumas protein analysis system (EAS, varioMax N/CN, Elt, Gouda, The Netherlands), using 6.25 as the conversion factor. The protein yield is the percentage of supernatant protein weight resulting from the BPC protein mixture. Protein contents of the AS and $\mathrm{EtOH}$ fractions were determined using Lowry's colorimetric method (26). To that end, the AS fractions were dissolved in $0.1 \mathrm{~mol} / \mathrm{L}$ sodium phosphate buffer ( $\mathrm{pH} 7.0)$. $\mathrm{The} \mathrm{EtOH}$ fractions were dissolved in deionized water. The method was calibrated with a bovine serum albumin standard curve in the corresponding media. The protein yield of the fractions is the percentage of protein weight present in the fraction resulting from the hydrolysate protein weight.

Moisture and ash contents of the AS and $\mathrm{EtOH}$ fractions were determined according to AACC methods 44-15A and 08-12 (27), respectively. After hydrolysis, monosaccharide compositions of barley, malt, and BSG were determined by the method of Englyst and Cummings (28). Arabinoxylan (AX) content was calculated as 0.88 times the sum of xylose and arabinose after correction of the arabinose content for the presence of arabinogalactan peptide based on an arabinose/galactose ratio of 0.7 for barley flour and assuming that all of the arabinose of arabinogalactan peptide is present in the aqueous extract (29). Noncellulosic glucose polymer (NCG) was calculated as 0.9 times the glucose content.

Emulsifying Properties. Emulsifying properties were measured by the turbidimetric method of Pearce and Kinsella (30), with minor modifications. To prepare the emulsion, $7.0 \mathrm{~mL}$ of soy oil (Lesieur, Asnières-sur-Seine, France) and $21.0 \mathrm{~mL}$ of protein solution $(0.2 \%$ protein) in $9.0 \mathrm{mmol} / \mathrm{L}$ sodium phosphate buffer containing $35 \mathrm{mmol} / \mathrm{L}$ $\mathrm{NaCl}(\mathrm{pH} 7.0 ; I=50 \mathrm{mmol} / \mathrm{L})(31)$ were homogenized for $60 \mathrm{~s}$ at speed 1 and $25{ }^{\circ} \mathrm{C}$ in a Waring blender (Torrington, CT). Immediately and 30 min after emulsion formation, a $50 \mu \mathrm{L}$ sample was withdrawn from the bottom of the cup and diluted with $10.0 \mathrm{~mL}$ of a $0.1 \%(\mathrm{w} / \mathrm{v})$ sodium dodecyl sulfate (SDS) solution. The absorbances of the diluted emulsions were measured at $500 \mathrm{~nm}\left(A_{500}\right)$. The emulsifying activity index (EAI, $\mathrm{m}^{2} / \mathrm{g}$ ) was calculated as follows:

$$
\operatorname{EAI}(\mathrm{m} / \mathrm{g})=\frac{2 T \times 200}{\phi C} \text { and } \mathrm{T}=\frac{2.303 A_{500}}{L}
$$

where $A_{500}$ is the absorbance, $L$ is the light path $\left(10^{-2} \mathrm{~m}\right), \phi$ is the volume fraction of dispersed phase (0.25), $C$ is the concentration of protein $\left(\mathrm{g} / \mathrm{m}^{3}\right)$, $T$ is the turbidity, and 200 is the dilution factor. $\mathrm{EAI}_{0}$ is the emulsifying activity index immediately after emulsion formation, whereas $\mathrm{EAI}_{30}$ is the emulsifying activity index after $30 \mathrm{~min}$, and ES is the percentage of emulsion turbidity remaining after $30 \mathrm{~min}$. Determination of the emulsifying properties was performed in duplicate for each sample.

Foaming Properties. Foam was prepared with protein solution $(0.6 \%$ protein) in $9.0 \mathrm{mmol} / \mathrm{L}$ sodium phosphate buffer containing $35 \mathrm{mmol} / \mathrm{L}$ $\mathrm{NaCl}(\mathrm{pH} 7.0 ; I=50 \mathrm{mmol} / \mathrm{L})(31)$, with the whipping method described by Caessens et al. (19). A volume of $100 \mathrm{~mL}$ of hydrolysate solution was placed in a graduated glass cylinder (diameter of $60 \mathrm{~mm}$ ) and whipped for $70 \mathrm{~s}$ by a propeller rotating at $2000 \mathrm{rpm}$ and $25^{\circ} \mathrm{C}$. The foam-forming ability $\left(F_{0}, \mathrm{~mL} / \mathrm{g}\right)$ is defined as the initial foam volume measured at $2 \mathrm{~min}$ after the start of whipping per protein weight. Foam volume loss was monitored during $60 \mathrm{~min}$. Whereas $F_{60}$ is the foam-forming ability measured at $60 \mathrm{~min}$ after the start of whipping per protein weight, FS is the percentage of the initial foam volume remaining after $60 \mathrm{~min}$. The coefficients of variation for a 5 -fold determination of $F_{0}$ and $\mathrm{FS}$ of a standard sample did not exceed $10 \%$.

Size-Exclusion High-Performance Liquid Chromatography (SEHPLC). SE-HPLC was performed with a Superdex Peptide 10/300 GL-column (GE Healthcare, Uppsala, Sweden) at $25{ }^{\circ} \mathrm{C}$ with a flow rate of $0.5 \mathrm{~mL} / \mathrm{min}$ and a sample injection volume of $100 \mu \mathrm{L}$ using an AKTA Explorer 100 (GE Healthcare). The mobile phase was $30 \%$ acetonitrile containing $0.15 \%$ trifluoroacetic acid in Milli-Q water. The column was calibrated with six MW markers: ribonuclease A $(\mathrm{MW}=13700)$, aprotinin $(\mathrm{MW}=6500)$, insulin chain $\mathrm{B}(\mathrm{MW}=3500)$,
Ala-Ser-His-Leu-Gly-Leu-Ala-Arg $(\mathrm{MW}=824),(\text { Ala })_{5}(\mathrm{MW}=$ 373), and Ala-Gln (MW = 217) (Sigma-Aldrich). A logarithmic calibration curve was constructed from the MW of the markers and their respective elution times $\left(R^{2}=0.96\right)$. Samples containing $0.1 \%$ protein were dissolved in the mobile phase, and the elution was monitored at $214 \mathrm{~nm}$.

Surface Hydrophobicity. The surface hydrophobicity $\left(\mathrm{S}_{0}\right)$ of a protein is an index of the number of hydrophobic groups on its surface in contact with the polar aqueous environment. The protein surface hydrophobicities of the BPC hydrolysates and fractions were determined with 1-anilino-8-naphthalene sulfonate (ANS) as the fluorescent probe (12). Samples containing $0.1 \%$ protein were dispersed in $0.01 \mathrm{~mol} / \mathrm{L}$ sodium phosphate buffer $(\mathrm{pH} 7.0)$, shaken for $16 \mathrm{~h}$ at room temperature, and subsequently centrifuged ( $3000 \mathrm{~g}$ for $10 \mathrm{~min}$ at $4{ }^{\circ} \mathrm{C}$ ). Supernatants were serially diluted with $0.01 \mathrm{~mol} / \mathrm{L}$ sodium phosphate buffer $(\mathrm{pH} 7.0)$ to obtain protein concentrations ranging from 0.01 to $0.16 \mathrm{mg} / \mathrm{mL}$. A $10 \mu \mathrm{L}$ aliquot of ANS solution $[8 \mathrm{mmol} / \mathrm{L}$ in $0.01 \mathrm{~mol} / \mathrm{L}$ sodium phosphate buffer ( $\mathrm{pH} 7.0)$ ] was added to $1.0 \mathrm{~mL}$ of each sample (in duplicate). The fluorescence intensity of the protein material was measured with a spectrofluorometer (Fluorolog-3 Model FL3-22, Horiba Jobin Yvon, Edison, NJ) using a $3 \mathrm{~nm}$ slit width. Wavelengths of excitation and emission were 390 and $480 \mathrm{~nm}$, respectively. The fluorescence intensity of each control solution (without ANS) was subtracted from that with ANS to obtain the net fluorescence intensity at each concentration. The initial slope of a plot of fluorescence intensity as a function of the protein concentration was used as an index of protein surface hydrophobicity $\left(\mathrm{S}_{0}\right)$ (12). The determination of $\mathrm{S}_{0}$ was performed in duplicate for each sample.

\section{RESULTS}

Enzymatic Hydrolysis of BPC Proteins. "Large scale" enzymatic hydrolysis of BPC by Alcalase for 1.7 and 120 min resulted in hydrolysates with low $(1.0 \%)$ and high $(9.0 \%) \mathrm{DH}$, respectively. After centrifugation and freeze-drying, 74 and $126 \mathrm{~g}$ of material (db) were obtained upon hydrolysis for 1.7 and $120 \mathrm{~min}$, respectively. The 1.0 and $9.0 \% \mathrm{DH}$ hydrolysates are further referred to as Alc01 and Alc09, respectively. The protein content in the supernatants $(58 \%)$, determined with the Dumas method, was somewhat lower than reported earlier (1). The levels of protein recovered in the supernatants of Alc01 and Alc09 were 49 and $84 \%$, respectively, which is in agreement with and somewhat lower than what was observed for the hydrolysates obtained after hydrolysis in the $\mathrm{pH}$-stat setup for 1.7 and $120 \mathrm{~min}$, respectively (1). Next to proteins, Alc01 and Alc09 contained ash $[18 \%(\mathrm{db})], \mathrm{AX}$ [2 and $1 \%(\mathrm{db})$, respectively], and NCG [4 and $2 \%(\mathrm{db})$, respectively].

Fractionation of BPC Hydrolysates. Because the principles causing precipitation of proteins and peptides by EtOH or AS are different, Alc01 and Alc09 were fractionated by these two graded precipitation processes. Whereas the main effect of EtOH precipitation is the reduction in water activity, AS precipitation is based on "salting in" at low AS concentrations and "salting out" at high AS concentrations. "Salting out" largely depends upon the hydrophobicity of the proteins, whereas "salting in" heavily depends upon surface charge distribution and polar interactions with the solvent (32). The hydrolysates were fractionated with AS into three fractions, which were recovered following precipitation at $\mathrm{AS}$ concentrations of $40 \%\left(\mathrm{AS}_{0-40}\right)$, between 40 and $60 \%\left(\mathrm{AS}_{40-60}\right)$, and above $60 \%\left(\mathrm{AS}_{60+}\right)$. Apart from this, Alc01 and Alc09 were also fractionated with EtOH into four fractions, precipitating at $\mathrm{EtOH}$ concentrations of $70 \%$ $\left(\mathrm{EtOH}_{0-70}\right)$, between 70 and $80 \%\left(\mathrm{EtOH}_{70-80}\right)$, between 80 and $90 \%\left(\mathrm{EtOH}_{80-90}\right)$, and above $90 \%\left(\mathrm{EtOH}_{90+}\right)$.

Table 1 shows the protein contents of the AS and EtOH fractions. $\mathrm{AS}_{40-60}$ obtained by fractionation of $\mathrm{Alc} 01$ and Alc09 and $\mathrm{AS}_{0-40}$ resulting from fractionation of Alc01 had high protein contents. Whereas the EtOH fractions resulting from 
Table 1. Yields (\%), Protein Contents [\% (db)], and Protein Yields (\%) of Fractions Obtained after Graded AS and EtOH Precipitation of Hydrolysates Resulting from Enzymatic Hydrolysis of BPC with Alcalase for $1.7 \mathrm{~min}$ (Alc01) and $120 \mathrm{~min}(\mathrm{Alc09})^{a}$

\begin{tabular}{|c|c|c|c|c|c|c|}
\hline \multirow[b]{2}{*}{ fractions } & \multicolumn{3}{|c|}{ Alc01 } & \multicolumn{3}{|c|}{ Alc09 } \\
\hline & yield (\%) & protein content $[\%(\mathrm{db})]$ & protein yield (\%) & yield (\%) & protein content $[\%(\mathrm{db})]$ & protein yield (\%) \\
\hline $\mathrm{AS}_{0-40}$ & 50 & 85 & 73 & 51 & 53 & 46 \\
\hline $\mathrm{AS}_{40-60}$ & 3 & 99 & 6 & 4 & 88 & 6 \\
\hline $\mathrm{AS}_{60+}$ & 9 & 66 & 10 & 9 & 57 & 9 \\
\hline $\mathrm{EtOH}_{0-70}$ & 33 & 85 & 39 & 21 & 62 & 22 \\
\hline $\mathrm{EtOH}_{70-80}$ & 22 & 40 & 12 & 18 & 37 & 12 \\
\hline $\mathrm{EtOH}_{80-90}$ & 12 & 85 & 14 & 16 & 67 & 19 \\
\hline $\mathrm{EtOH}_{90+}$ & 33 & 76 & 35 & 45 & 59 & 47 \\
\hline
\end{tabular}

${ }^{a}$ Whereas yields of the fractions are expressed as the percentage of fraction weight resulting from the hydrolysate weight, protein yields of the fractions are expressed as the percentages of fraction protein weight resulting from the hydrolysate protein weight.

Table 2. $A X, N C G$, and Ash Contents [\% (db)] of Fractions Obtained after Graded AS and EtOH Precipitation of Hydrolysates Resulting from Enzymatic Hydrolysis of BPC with Alcalase for $1.7 \mathrm{~min}$ (Alc01) and $120 \mathrm{~min}$ (Alc09)

\begin{tabular}{|c|c|c|c|c|c|c|}
\hline \multirow[b]{2}{*}{ fractions } & \multicolumn{3}{|c|}{ Alc01 } & \multicolumn{3}{|c|}{ Alc09 } \\
\hline & $\mathrm{AX}$ content $[\%(\mathrm{db})]$ & NCG content $[\%(\mathrm{db})]$ & ash content $[\%(\mathrm{db})]$ & $A X$ content $[\%(d b)]$ & NCG content $[\%(\mathrm{db})]$ & ash content $[\%(\mathrm{db})]$ \\
\hline $\mathrm{AS}_{0-40}$ & 1.3 & 0.5 & 0.4 & 0.9 & 0.5 & 1.1 \\
\hline $\mathrm{AS}_{40-60}$ & 2.7 & 0.6 & $\mathrm{nd}^{a}$ & 2.0 & 0.5 & $\mathrm{nd}^{\mathrm{a}}$ \\
\hline $\mathrm{AS}_{60+}$ & 8.8 & 6.1 & 2.1 & 6.8 & 2.8 & 1.4 \\
\hline $\mathrm{EtOH}_{0-70}$ & 4.5 & 2.7 & 7.2 & 5.0 & 2.3 & 6.7 \\
\hline $\mathrm{EtOH}_{70-80}$ & 0.1 & 0.6 & 42.4 & 0.2 & 0.6 & 43.0 \\
\hline $\mathrm{EtOH}_{80-90}$ & 0.2 & 6.3 & 6.8 & 0.2 & 3.3 & 11.7 \\
\hline $\mathrm{EtOH}_{90+}$ & 0.02 & 5.3 & 14.0 & 0.0 & 2.1 & 6.1 \\
\hline
\end{tabular}

${ }^{a} \mathrm{nd}=$ not determined.

fractionation of Alc09 had protein contents lower than $75 \%$, the EtOH fractions obtained by fractionation of Alc01 showed protein contents exceeding $75 \%$, with the exception of $\mathrm{EtOH}_{70-80}$. Table 1 also presents the yields and protein yields of the AS and EtOH fractions. The data for the AS fractions indicate that most of the material, including proteins, were present in $\mathrm{AS}_{0-40}$. High levels of material, including proteins, were lost during AS fractionation, because of dialysis against deionized water (6000-8000 MWCO) to remove AS. Whereas EtOH fractionation of Alc09 resulted in $\mathrm{EtOH}_{90+}$, which contained $47 \%$ of the Alc09 proteins, EtOH fractionation of Alc01 showed similar protein yields of $\mathrm{EtOH}_{0-70}$ and $\mathrm{EtOH}_{90+}(39$ and $35 \%$, respectively) (Table 1).

Because some AS or EtOH fractions contained low levels of protein, we characterized the nonprotein material. Table $\mathbf{2}$ shows the AX, NCG, and ash contents of the AS and EtOH fractions. The $\mathrm{EtOH}_{70-80}$ fractions obtained after fractionation of Alc01 and Alc09, which consisted of less than $40 \%$ protein material, contained high levels of ash (ca. 43\%). In these fractions, 52 and $43 \%$ of the ash material of the hydrolysates Alc01 and Alc09, respectively, are recovered. The AX content of $\mathrm{EtOH}_{0-70}$ was higher than that of the other EtOH fractions, whereas AS fractionation of $\mathrm{Alc} 01$ and Alc09 resulted in $\mathrm{AS}_{60}+$ with higher AX content than $\mathrm{AS}_{0-40}$ and $\mathrm{AS}_{40-60}$. $\mathrm{EtOH}_{70-80}$ contained the lowest level of NCG of all of the EtOH fractions. The NCG content was higher for $\mathrm{AS}_{60+}$ than for $\mathrm{AS}_{0-40}$ and $\mathrm{AS}_{40-60}$. Because the hydrolysates Alc01 and Alc09 consisted of 4 and 2\% NCG, respectively, 14 and $12 \%$ of NCG of Alc01 and Alc09, respectively, were recovered in the respective $\mathrm{AS}_{60+}$ fractions.

Emulsifying Properties. Figure 1 shows the EAI and ES, measured at $\mathrm{pH}$ 7.0, of the hydrolysates Alc01 and Alc09 and their EtOH and AS fractions. The $\mathrm{EAI}_{0}$ was determined immediately after emulsion formation, whereas $\mathrm{EAI}_{30}$ was determined $30 \mathrm{~min}$ later. ES is the percentage of emulsion turbidity remaining after $30 \mathrm{~min}$. The emulsifying properties of SE70M, a commercially available product with good emulsifying properties, were determined with the same methods. This resulted in $\mathrm{EAI}_{0}$ of $55 \mathrm{~m}^{2} / \mathrm{g}$ (standard deviation of $3.0 \%$ ), $\mathrm{EAI}_{30}$ of $32 \mathrm{~m}^{2} / \mathrm{g}$ (standard deviation of $2.9 \%$ ), and ES of $59 \%$ (standard deviation of $2.4 \%$ ). Alc01 and Alc09 and most of their AS and $\mathrm{EtOH}$ fractions showed $\mathrm{EAI}_{0}$ values exceeding those of SE70M. Only EtOH $\mathrm{H}_{0-70}$ and $\mathrm{AS}_{40-60}$ obtained by fractionation of Alc01 had somewhat lower $\mathrm{EAI}_{0}$ values.

Because the $\mathrm{EtOH}_{70-80}$ fractions contained ca. $43 \%$ ash, the effect of ash on the emulsifying properties was evaluated. The emulsifying properties of Alc09 and SE70M were similar or even decreased when evaluated in $9.0 \mathrm{mmol} / \mathrm{L}$ sodium phosphate buffer containing $80 \mathrm{mmol} / \mathrm{L} \mathrm{NaCl}(\mathrm{pH} 7.0 ; I=100 \mathrm{mmol} / \mathrm{L})$, which corresponds to the addition of $43 \% \mathrm{NaCl}$ (results not shown). Moreover, the emulsifying properties of $\mathrm{EtOH}_{70-80}$, desalted on a Biogel P4 column, were similar or even higher than the emulsifying properties of $\mathrm{EtOH}_{70-80}$ (results not shown). This indicates that ash has no effect on the emulsifying properties.

Some fractions resulting from fractionation of $\mathrm{Alc01}$ $\left(\mathrm{EtOH}_{90+}, \mathrm{AS}_{40-60}\right.$, and $\left.\mathrm{AS}_{60+}\right)$ and some fractions obtained by fractionating Alc09 $\left(\mathrm{EtOH}_{90+}, \mathrm{AS}_{0-40}, \mathrm{AS}_{40-60}\right.$, and $\left.\mathrm{AS}_{60+}\right)$ had $\mathrm{EAI}_{30}$ and $\mathrm{ES}$ values exceeding those of SE70M $\left(32 \mathrm{~m}^{2} / \mathrm{g}\right.$ and $59 \%$, respectively). $\mathrm{EtOH}_{0-70}$ obtained after fractionation of Alc01 yielded lower $\mathrm{EAI}_{30}$ and $\mathrm{ES}$ values than those of SE70M. Whereas $\mathrm{EAI}_{30}$ values of some fractions obtained by fractionation of Alc01 $\left(\mathrm{AS}_{0-40}, \mathrm{EtOH}_{70-80}\right.$, and $\left.\mathrm{EtOH}_{80-90}\right)$ and Alc09 $\left(\mathrm{EtOH}_{0-70}, \mathrm{EtOH}_{70-80}\right.$, and $\left.\mathrm{EtOH}_{80-90}\right)$ exceeded $32 \mathrm{~m}^{2} / \mathrm{g}$, their ES values were lower than that of SE70M.

Foaming Properties. Figure 2 shows the foaming properties of $\mathrm{Alc} 01$ and $\mathrm{Alc} 09$ and their $\mathrm{EtOH}$ and AS fractions at $\mathrm{pH}$ 7.0. The $F_{0}$ and $F_{60}$ values were determined, respectively, 2 and $60 \mathrm{~min}$ after the start of whipping, whereas FS is the percentage of foam volume remaining after $60 \mathrm{~min}$. The foam-forming capacities of 
(a)

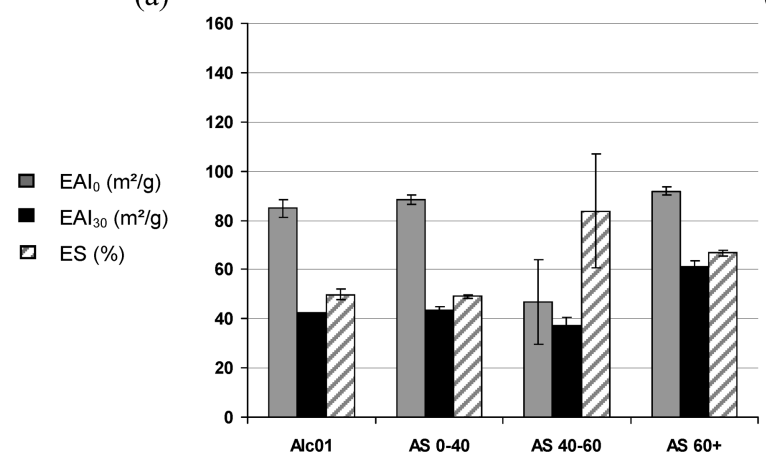

(c)
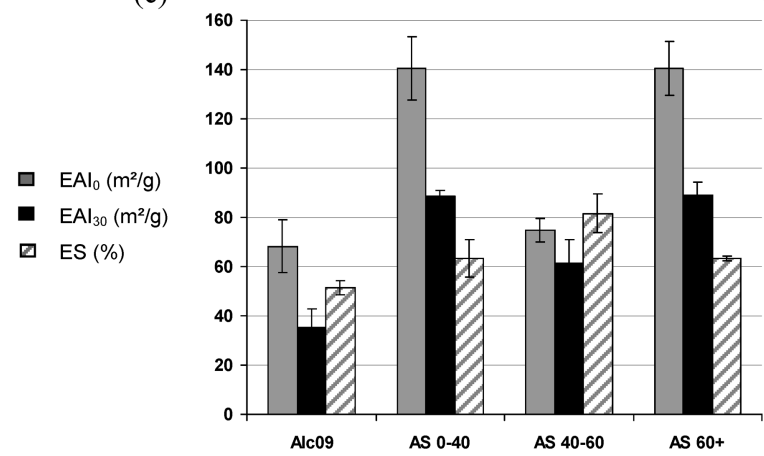

(b)

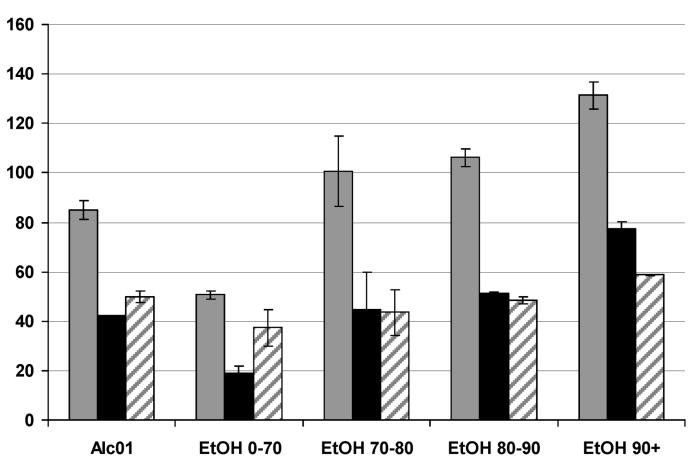

(d)

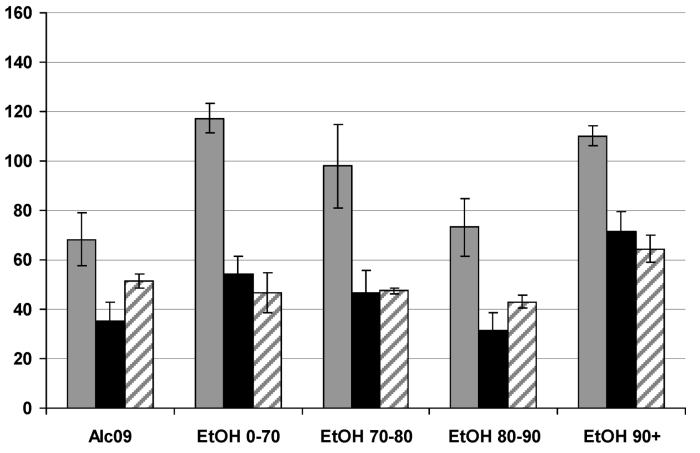

Figure 1. Emulsifying activity index $\left(\mathrm{m}^{2} / \mathrm{g}\right)$, immediately $\left(\mathrm{EAl}_{0}\right.$; unpatterned gray bars) and 30 min after emulsion formation ( $E A l_{30}$; unpatterned black bars), and emulsion stability (ES; \%) (patterned bars) at $\mathrm{pH} 7.0$ and $0.2 \%$ protein of hydrolysates obtained by enzymatic hydrolysis of BPC with Alcalase for 1.7 min (Alc01; $a$ and $b$ ) and 120 min (Alc09; $c$ and d) and their fractions resulting from graded AS precipitation ( $a$ and $c$ ) and graded EtOH precipitation (b and d). Each of the columns and error bars represents the average and standard deviation of EAI and ES, respectively.

Hyfoama 77 and Versa Whip 510, two commercially available products with high foam-forming capacity, were evaluated for comparison reasons. Hyfoama 77 and Versa Whip 510 showed $F_{0}$ values of 100 and $109 \mathrm{~mL} / \mathrm{g}$, respectively, while $F_{60}$ of these commercially available products were 66 and $62 \mathrm{~mL} / \mathrm{g}$, respectively. The FS of Hyfoama 77 and Versa Whip 510 were 65 and $57 \%$, respectively. Alc01 had a $F_{0}$ value comparable to those of the commercially available products, whereas Alc09 had a lower $F_{0}$. Some fractions resulting from fractionation of Alc01 $\left(\mathrm{AS}_{0-40}\right.$ and $\left.\mathrm{EtOH}_{90+}\right)$ and Alc09 $\left(\mathrm{AS}_{0-40}, \mathrm{AS}_{40-60}, \mathrm{EtOH}_{0-70}\right.$, and $\left.\mathrm{EtOH}_{90+}\right)$ showed $F_{0}$ values lower than $100 \mathrm{~mL} / \mathrm{g}$.

As for the emulsifying properties, the foaming properties of Hyfoama 77 and Alc09 were similar or even lower in $9.0 \mathrm{mmol} / \mathrm{L}$ sodium phosphate buffer containing $164 \mathrm{mmol} / \mathrm{L} \mathrm{NaCl}(\mathrm{pH} 7.0$; $I=180 \mathrm{mmol} / \mathrm{L}$ ) than in $9.0 \mathrm{mmol} / \mathrm{L}$ sodium phosphate buffer containing $35 \mathrm{mmol} / \mathrm{L} \mathrm{NaCl}$. This indicates that ash has no effect on the foaming properties.

FS and $F_{60}$ of $\mathrm{EtOH}_{70-80}$ and $\mathrm{EtOH}_{80-90}$ resulting from fractionation of Alc01 and Alc09 were higher than those of Hyfoama 77 and Versa Whip 510. All AS fractions obtained from Alc09, $\mathrm{AS}_{40-60}$ and $\mathrm{AS}_{60}$ obtained from Alc01, and the $\mathrm{EtOH}_{0-70}$ fractions obtained from Alc01 and Alc09 had lower FS and $F_{60}$ than those of the commercially available products. $\mathrm{EtOH}_{90}+$ obtained after fractionation of Alc01 and Alc09 and $\mathrm{AS}_{0-40}$ resulting from fractionation of Alc01 showed FS values exceeding those of Hyfoama 77 and Versa Whip 510. However, their $F_{60}$ were lower than those of the commercially available products.

SE-HPLC. To relate the emulsifying and foaming properties with the protein or peptide molecular characteristics, fractions with protein contents exceeding $75 \%(\mathrm{db})$ were selected and their MW distributions were determined. The SE-HPLC profiles of the fractions obtained after graded AS and $\mathrm{EtOH}$ precipitation of
Alc01 and Alc09 were divided into three fractions based on their apparent MW (Figure 3), as described by Celus et al. (1). Fraction I includes the first peak and corresponds to protein fragments with MW exceeding 14500; fraction II corresponds to protein fragments with MW between 1700 and 14 500; and fraction III corresponds to protein fragments with MW lower than 1700 . Table 3 shows the area percentage of each fraction relative to the total area of the SE-HPLC chromatogram. The fractions that contained less than $75 \%$ protein $(\mathrm{db})$ were excluded from Table 3 because of the presence of high levels of nonprotein material.

The average MWs of both the AS and EtOH fractions decreased with increasing AS and EtOH concentrations. Whereas $\mathrm{EtOH}_{0-70}$ consisted of high levels of protein fragments with MW exceeding 14 500, the protein fragments present in $\mathrm{EtOH}_{90}$, had MW lower than 14500 (Table 3).

Surface Hydrophobicity. Figure 4 shows the $S_{0}$ of the fractions obtained after graded $\mathrm{AS}$ and $\mathrm{EtOH}$ precipitation of Alc01 and Alc09. The figure $\mathbf{4}$ does not show fractions with protein contents lower than $75 \%(\mathrm{db})$.

In general, the surface hydrophobicities of both the AS and $\mathrm{EtOH}$ fractions decreased with increasing AS and EtOH concentrations. Fractionation of Alc01 resulted in $\mathrm{AS}_{40-60}$ with very low $S_{0}$.

\section{DISCUSSION}

Hydrolysates prepared by enzymatic hydrolysis of BPC with Alcalase with low and high $\mathrm{DH}$ were fractionated with graded EtOH and AS precipitation to obtain fractions homogeneous in terms of MW and hydrophobicity. The emulsifying and foaming properties of the fractions were compared to those of commercially available products with good emulsifying or foaming properties. To relate these technofunctional properties with the protein or peptide molecular characteristics, the MW 
(a)

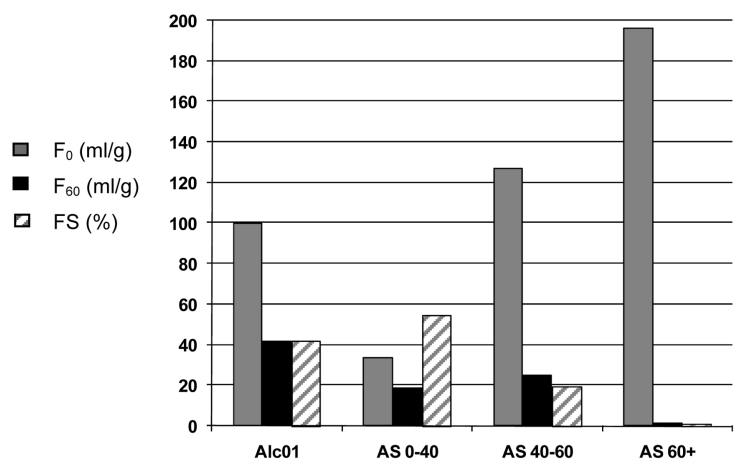

(c)

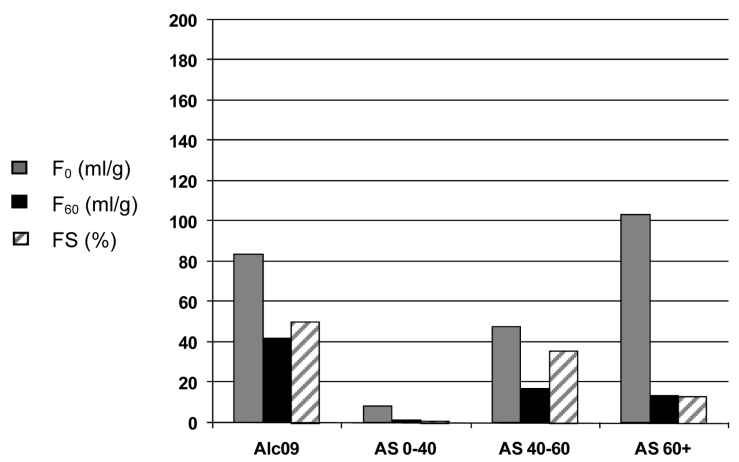

(b)

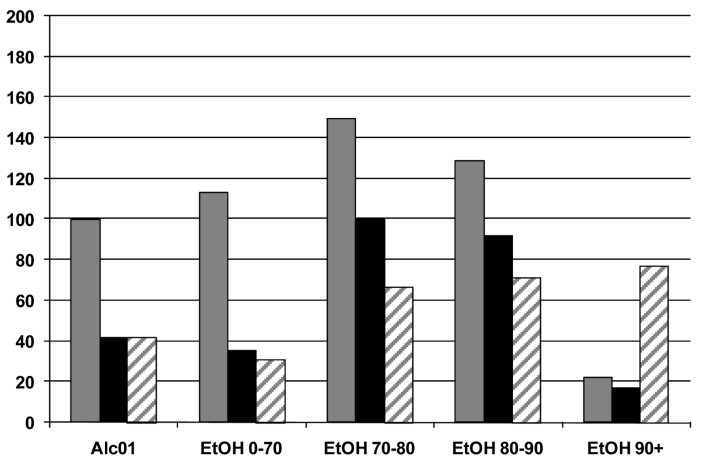

(d)

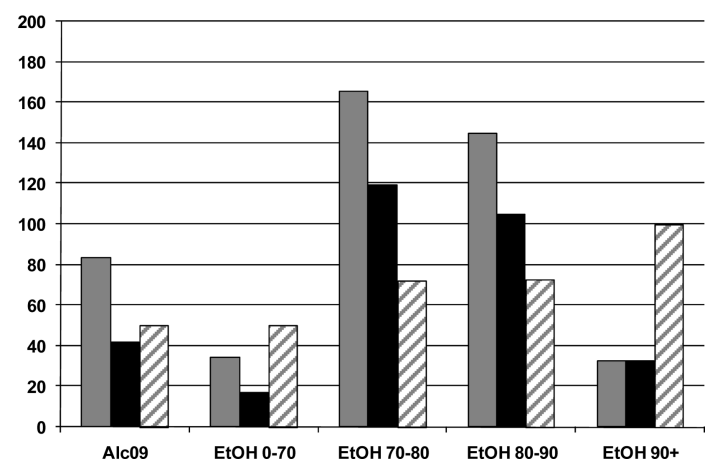

Figure 2. Foam-forming ability $(\mathrm{mL} / \mathrm{g}), 2 \mathrm{~min}$ ( $F_{0}$; unpatterned gray bars) and $60 \mathrm{~min}$ ( $F_{60}$; unpatterned black bars) after the start of whipping, and foam stability (FS; \%) (patterned bars) at pH 7.0 and $0.6 \%$ protein of hydrolysates obtained by enzymatic hydrolysis of BPC with Alcalase for $1.7 \mathrm{~min}$ (Alc01; a and b) and 120 $\min ($ Alc09; $c$ and $d)$ and their fractions resulting from graded AS precipitation ( $a$ and $c$ ) and graded EtOH precipitation (b and d).

Table 3. Apparent MW Distribution of Fractions Obtained after Graded AS and EtOH Precipitation of Hydrolysates Resulting from Enzymatic Hydrolysis of BPC with Alcalase for $1.7 \mathrm{~min}$ (Alc01) and $120 \mathrm{~min}$ (Alc09) and with Protein Contents Exceeding $75 \%(\mathrm{db})^{a}$

\begin{tabular}{lccc}
\hline \multicolumn{1}{c}{ sample } & fraction I & fraction II & fraction III \\
\hline $\mathrm{AS}_{0-40}$ (Alc01) & 31 & 65 & 4 \\
$\mathrm{AS}_{40-60}$ (Alc01) & 2 & 95 & 3 \\
$\mathrm{AS}_{40-60}$ (Alc09) & 3 & 89 & 8 \\
$\mathrm{EtOH}_{0-70}$ (Alc01) & 63 & 37 & 0 \\
$\mathrm{EtOH}_{80-90}$ (Alc01) & $\mathrm{nd}$ & 95 & 5 \\
$\mathrm{EtOH}_{90+}$ (Alc01) & $\mathrm{nd}^{b}$ & 55 & 45 \\
\hline
\end{tabular}

${ }^{a}$ The MW distribution is expressed as the area percentage of each fraction relative to the total area of SE-HPLC chromatogram (detection at $214 \mathrm{~nm}$ ). SE-HPLC profiles are divided into three fractions based on their MW. Fraction I corresponds to protein fragments with MW exceeding 14500; fraction II corresponds to protein fragments with MW between 1700 and 14500; and fraction III corresponds to material with MW lower than $1700 .{ }^{b} \mathrm{nd}=$ not detectable.

distributions and surface hydrophobicities were only determined for fractions with protein contents exceeding $75 \%(\mathrm{db})$.

The fractions with lower EAI than SE70M $\left(\mathrm{EtOH}_{0-70}\right.$ and $\mathrm{AS}_{40-60}$ obtained after fractionation of Alc01) contained higher levels of protein fragments with MW exceeding 14500 than of such fragments with MW between 1700 and 14500 or showed very low $S_{0}$. The other AS and EtOH fractions with EAI higher than that of the commercially available product contained less than $40 \%$ of protein fragments with MW exceeding 14500 and had $S_{0}$ exceeding $10 \times 10^{5}$. According to Damodaran (33), small peptides migrate quickly and adsorb to oil-water interfaces. $\mathrm{Wu}$ et al. (12) and Kim et al. (16) also demonstrated high emulsifying activities of soy and maize protein hydrolysate fractions with LMW, respectively. The minimum hydrophobicity needed to obtain favorable emulsifying properties can probably be ascribed to enhanced interaction between hydrolyzed proteins and lipids at oil-water interfaces as a result of the exposure of hydrophobic groups upon enzymatic hydrolysis, in accordance with the literature. Gluten hydrolysate fractions enriched in hydrophobic peptides indeed show good emulsifying properties (3, 7-9). Jung et al. (14) and Qi et al. (13) demonstrated a high correlation between surface hydrophobicity and emulsifying activity of soy protein hydrolysates. However, Wu et al. (12) demonstrated higher emulsifying activity but lower $S_{0}$ of soy protein hydrolysate fractions.

Whereas some fractions resulting from fractionation of Alc01 ( $\mathrm{AS}_{40-60}$ and $\left.\mathrm{EtOH}_{90+}\right)$ and $\mathrm{Alc09}\left(\mathrm{AS}_{40-60}\right)$ had ES and $\mathrm{EAI}_{30}$ values exceeding those of $\mathrm{SE70M}, \mathrm{EtOH}_{0-70}$ obtained by fractionation of Alc01 showed lower ES and $\mathrm{EAI}_{30}$ than SE70M. It should be noticed that $\mathrm{EtOH}_{0-70}$ contained higher levels of protein fragments with MW exceeding 14500 than of such fragments with MW between 1700 and 14500 and/ or showed high $S_{0}$. Therefore, protein fragments with less than $50 \%$ of the protein with MW exceeding 14500 and/or $S_{0}$ lower than $30 \times 10^{5}$ may result in high ES. These results are at variance with some literature data, which propose that proteins form a more stable viscoelastic film at the interface than small MW surfactants $(6,33)$. However, Kim et al. (16) demonstrated higher ES for maize gluten hydrolysate fractions with MW lower than 5000.

The $F_{0}$ of some fractions resulting from fractionation of $\mathrm{Alc} 01\left(\mathrm{AS}_{40-60}, \mathrm{EtOH}_{0-70}\right.$, and $\left.\mathrm{EtOH}_{80-90}\right)$ exceeded $100 \mathrm{~mL} / \mathrm{g}$. The fractions with $F_{0}$ values lower than those of the commercially available products $\left(\mathrm{AS}_{40-60}\right.$ obtained after fractionation of $\mathrm{Alc} 09$ and $\mathrm{AS}_{0-40}$ and $\mathrm{EtOH}_{90+}$ resulting from fractionation of Alc 01 ) contained more than $10 \%$ of the protein fragments with MW lower than 1700 or showed $S_{0}$ values exceeding $20 \times 10^{5}$. However, $\mathrm{EtOH}_{0-70}$ obtained after 

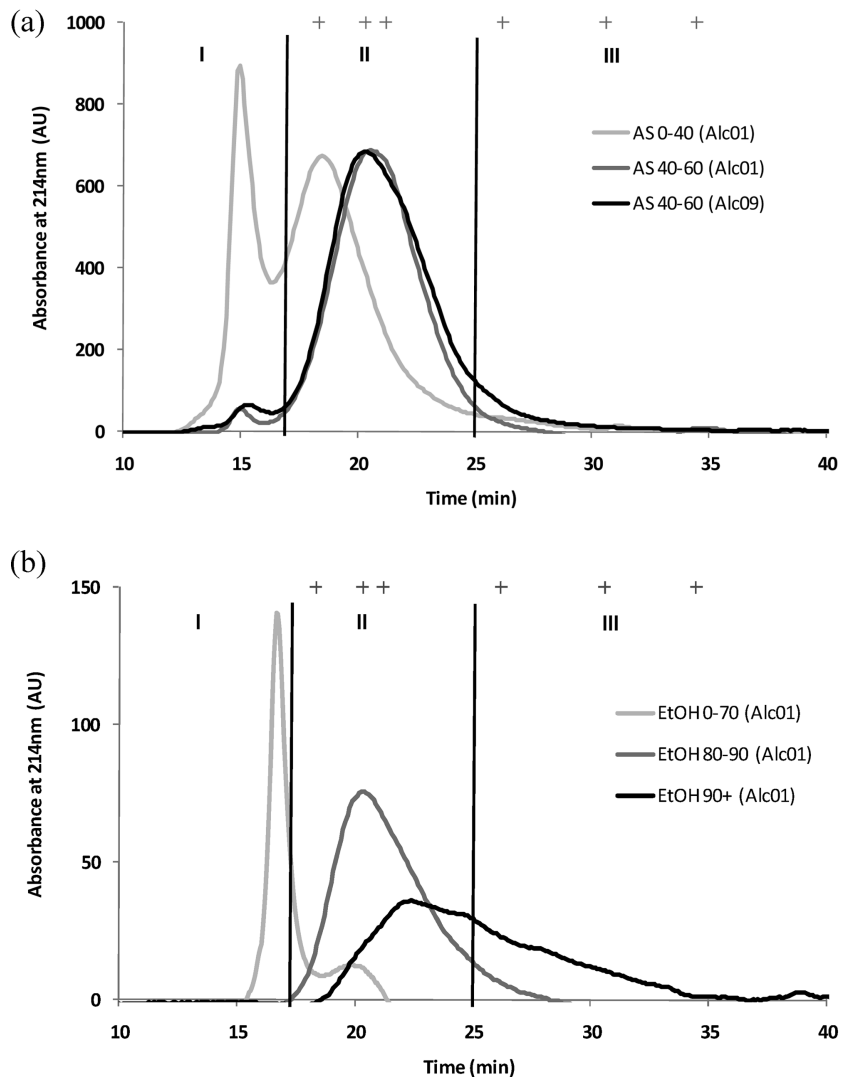

Figure 3. SE-HPLC profiles of fractions obtained after graded AS (a) and $\mathrm{EtOH}$ (b) precipitation of hydrolysates resulting from enzymatic hydrolysis of BPC with Alcalase for $1.7 \mathrm{~min}$ (Alc01) and $120 \mathrm{~min}$ (Alc09) with protein contents exceeding $75 \%$ (db). Elution times of MW markers with MW 13700 , $6500,3500,824,373$, and 217 are indicated from left to right with + symbols. SE-HPLC profiles are divided into three fractions: protein fragments with MW exceeding 14500 (fraction I), protein fragments with MW between 1700 and 14500 (fraction II), and protein fragments with MW lower than 1700 (fraction III). Absorbance $(214 \mathrm{~nm})$ is expressed in arbitrary units (AU).

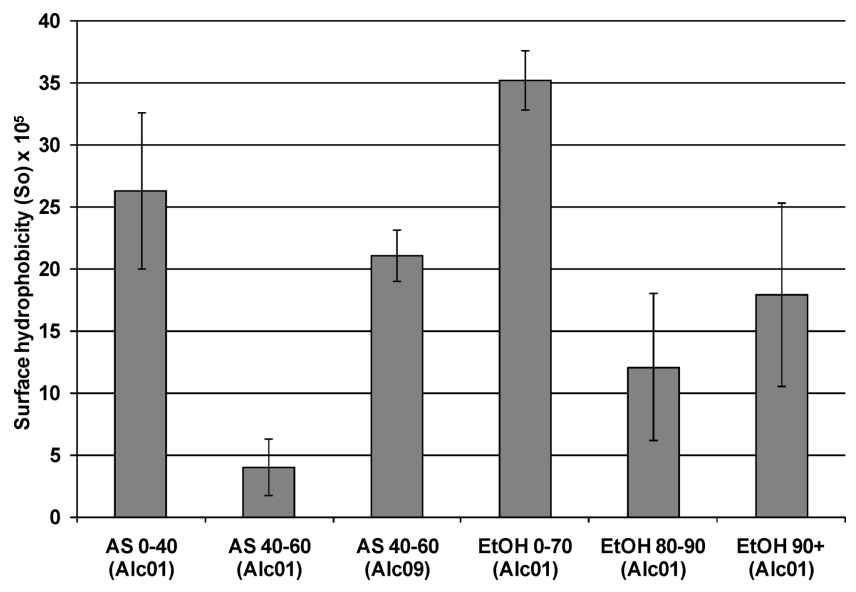

Figure 4. Surface hydrophobicity $\left(S_{0}\right)$ of fractions obtained after graded $\mathrm{AS}$ and $\mathrm{EtOH}$ precipitation of hydrolysates resulting from enzymatic hydrolysis of BPC with Alcalase for $1.7 \mathrm{~min}$ (Alc01) and $120 \mathrm{~min}$ (Alc09) and with protein contents exceeding $75 \%(\mathrm{db})$. Each of the columns and error bars represents the average and standard deviation of $S_{0}$, respectively.

fractionation of Alc01 had $S_{0}$ values exceeding $20 \times 10^{5}$ and showed high $F_{0}$ values. This could be explained by the higher levels of protein fragments of MW exceeding 14500 than of such fragments of MW in a 1700-14 500 range. These results are at variance with the literature data, where the increase in foaming capacity of gluten hydrolysate fractions is obviously associated with increased surface hydrophobicity $(3,8,9)$. However, Ortiz and Wagner (15) showed a greater impact of protein solubility than of surface hydrophobicity on the foaming properties of soy protein hydrolysates. According to Adler-Nissen and Olsen (11), the optimum peptide size of soy proteins lies between 15 and 35 amino acids for good foaming properties, in line with our results.

Whereas fraction $\mathrm{EtOH}_{80-90}$ obtained after fractionation of Alc01 showed FS and $F_{60}$ values exceeding those of the commercially available products, fractions resulting from fractionation of Alc01 $\left(\mathrm{AS}_{40-60}\right.$ and $\left.\mathrm{EtOH}_{0-70}\right)$ and $\mathrm{Alc} 09\left(\mathrm{AS}_{40-60}\right)$ resulted in low FS and $F_{60}$ values. These results may indicate that $S_{0}$ should be between $10 \times 10^{5}$ and $20 \times 10^{5}$ and/or less than $10 \%$ of the protein fragments should have MW exceeding 14500 to exert a favorable foam-stabilizing effect. These results are at variance with research data on gluten hydrolysates $(3,4)$, which indicated that FS decreases as MW decreases.

In conclusion, fractionation of the BSG protein hydrolysates resulted in homogeneous peptide fractions. It became clear that the physicochemical properties required for emulsifying properties differ from those required for foaming properties. As outlined above, literature on protein hydrolysates is ambiguous about relationships between physicochemical and emulsifying and foaming properties and research reports generally focus on either MW $(11)$ or $S_{0}(3,8,9)$ in relation to the emulsifying and foaming properties. This paper provides good evidence that neither MW nor hydrophobicity solely determine the emulsifying and foaming properties.

While, for favorable emulsifying activities of the BSG hydrolysate fractions, less than $40 \%$ of the proteins/peptides had MW exceeding 14500 , the BSG hydrolysate fractions had favorable foaming activities provided that they did not contain more than $10 \%$ of protein fragments with $\mathrm{MW}$ lower than 1700. Moreover, favorable emulsifying activities went hand in hand with $S_{0}$ exceeding $10 \times 10^{5}$, while good foaming activities were accompanied by $S_{0}$ lower than $20 \times 10^{5}$, except for protein hydrolysates with higher levels of protein fragments with MW exceeding 14500 than of such fragments with MW in a 1700-14500 range.

\section{ABBREVIATIONS USED}

ANS, 1-anilino-8-naphthalene sulfonate; AS, ammonium sulfate; BPC, brewers' spent grain protein concentrate; BSG, brewers' spent grain; DH, degree of hydrolysis; $\mathrm{EAI}_{0}$, emulsifying activity index (immediately after emulsion formation); $\mathrm{EAI}_{30}$, emulsifying activity index (30 min after emulsion formation); ES, emulsion stability; EtOH, ethanol; $F_{0}$, foam-forming ability ( 2 min after the start of whipping); $F_{60}$, foam-forming ability (60 min after the start of whipping); FS, foam stability; MW(s), molecular weight(s); MWCO, molecular weight cutoff; OPA, $o$-phthaldialdehyde; $S_{0}$, surface hydrophobicity; SE-HPLC, Size-exclusion high-performance liquid chromatography; SDS, sodium dodecyl sulfate.

\section{ACKNOWLEDGMENT}

This work was performed as part of the Katholieke Universiteit Leuven Methusalem program "Food for the Future". The Centre for Surface Chemistry and Catalysis (Katholieke Universiteit Leuven) is thanked for the use of the spectrofluorometer. Technical assistance by N. Schoonens (this laboratory) is gratefully appreciated. 


\section{LITERATURE CITED}

(1) Celus, I.; Brijs, K.; Delcour, J. A. Enzymatic hydrolysis of brewers' spent grain proteins and technofunctional properties of the resulting hydrolysates. J. Agric. Food Chem. 2007, 55, 8703-8710.

(2) Walstra, P.; van Vliet, T. Functional properties. In Industrial Proteins in Perspective; Aalbersberg, W. Y., Hamer, R. J., Jasperse, P., de Jongh, H. H. J., de Kruif, C. G., Walstra, P., de Wolf, F. A., Eds.; Elsevier Science B.V.: Amsterdam, The Netherlands, 2003; Vol. 23, pp 9-30.

(3) Wang, J. S.; Zhao, M. M.; Yang, X. Q.; Jiang, Y. M. Improvement on functional properties of wheat gluten by enzymatic hydrolysis and ultrafiltration. J. Cereal Sci. 2006, 44, 93-100.

(4) Wang, J. S.; Zhao, M. M.; Bao, Y.; Hong, T.; Rosella, C. M. Preparation and characterization of modified wheat gluten by enzymatic hydrolysis-ultrafiltration. J. Food Biochem. 2008, 32, 316-334.

(5) Adler-Nissen, J. Enzymic Hydrolysis of Food Proteins; Elsevier Applied Science Publishers: New York, 1985; p 427.

(6) Drago, S. R.; Gonzalez, R. J. Foaming properties of enzymatically hydrolysed wheat gluten. Innovative Food Sci. Emerging Technol. 2001, 1, 269-273.

(7) Chobert, J. M.; Briand, L.; Gueguen, J.; Popineau, Y.; Larre, C.; Haertle, T. Recent advances in enzymatic modifications of food proteins for improving their functional properties. Nahrung 1996, 40, 177-182.

(8) Berot, S.; Popineau, Y.; Compoint, J. P.; Blassel, C.; Chaufer, B. Ultrafiltration to fractionate wheat polypeptides. J. Chromatogr., B: Anal. Technol. Biomed. Life Sci. 2001, 753, 29-35.

(9) Popineau, Y.; Huchet, B.; Larre, C.; Berot, S. Foaming and emulsifying properties of fractions of gluten peptides obtained by limited enzymatic hydrolysis and ultrafiltration. J. Cereal Sci. 2002, $35,327-335$

(10) Mimouni, B.; Azanza, J. L.; Raymond, J. Influence of double enzymic hydrolyses on gluten functionality. J. Sci. Food Agric. 1999, 79, 1048-1053.

(11) Adler-Nissen, J.; Olsen, H. S. Influence of peptide chain-length on taste and functional properties of enzymatically modified soy protein. Abstr. Pap. Am. Chem. Soc. 1978, 175, 13.

(12) Wu, W. U.; Hettiarachchy, N. S.; Qi, M. Hydrophobicity, solubility, and emulsifying properties of soy protein peptides prepared by papain modification and ultrafiltration. J. Am. Oil Chem. Soc. 1998, 75, 845-850.

(13) Qi, M.; Hettiarachchy, N. S.; Kalapathy, U. Solubility and emulsifying properties of soy protein isolates modified by pancreatin. J. Food Sci. 1997, 62, 1110-1115.

(14) Jung, S.; Murphy, P. A.; Johnson, L. A. Physicochemical and functional properties of soy protein substrates modified by low levels of protease hydrolysis. J. Food Sci. 2005, 70, C180-C187.

(15) Ortiz, S. E. M.; Wagner, J. R. Hydrolysates of native and modified soy protein isolates: Structural characteristics, solubility and foaming properties. Food Res. Int. 2002, 35, 511-518.

(16) Kim, J. M.; Whang, J. H.; Suh, H. J. Enhancement of angiotensin I converting enzyme inhibitory activity and improvement of the emulsifying and foaming properties of corn gluten hydrolysate using ultrafiltration membranes. Eur. Food Res. Technol. 2004, 218, 133-138.

(17) Aluko, R. E.; Monu, E. Functional and bioactive properties of quinoa seed protein hydrolysates. J. Food Sci. 2003, 68, 1254-1258.
(18) Caessens, P. W. J. R.; Visser, S.; Gruppen, H.; van Aken, G. A.; Voragen, A. G. J. Emulsion and foam properties of plasmin derived $\beta$-casein peptides. Int. Dairy J. 1999, 9, 347-351.

(19) Caessens, P. W. J. R.; Gruppen, H.; Visser, S.; van Aken, G. A.; Voragen, A. G. J. Plasmin hydrolysis of $\beta$-casein: Foaming and emulsifying properties of the fractionated hydrolysate. J. Agric. Food Chem. 1997, 45, 2935-2941.

(20) Caessens, P. W. J. R.; Gruppen, H.; Slangen, C. J.; Visser, S.; Voragen, A. G. J. Functionality of $\beta$-casein peptides: Importance of amphipathicity for emulsion-stabilizing properties. J. Agric. Food Chem. 1999, 47, 1856-1862.

(21) van der Ven, C.; Gruppen, H.; de Bont, D. B. A.; Voragen, A. G. J. Emulsion properties of casein and whey protein hydrolysates and the relation with other hydrolysate characteristics. J. Agric. Food Chem. 2001, 49, 5005-5012.

(22) van der Ven, C.; Gruppen, H.; de Bont, D. B. A.; Voragen, A. G. J. Correlations between biochemical characteristics and foam-forming and -stabilizing ability of whey and casein hydrolysates. J. Agric. Food Chem. 2002, 50, 2938-2946.

(23) Celus, I.; Brijs, K.; Delcour, J. A. The effects of malting and mashing on barley protein extractability. J. Cereal Sci. 2006, 44, 203-211.

(24) Brijs, K.; Bleukx, W.; Delcour, J. A. Proteolytic activities in dormant rye (Secale cereale L.) grain. J. Agric. Food Chem. 1999, 47, 35723578.

(25) Association of Official Analytical Chemists (AOAC). Method 990.03. In Official Methods of Analysis, 16th ed.; AOAC: Washington, D.C., 1995.

(26) Lowry, O. H.; Rosebrough, N. J.; Farr, A. L.; Randall, R. J. Protein measurement with the folin phenol reagent. J. Biol. Chem. 1951, 193, 265-275.

(27) Amercan Association of Cereal Chemists (AACC). AACC Methods 44-15A, 08-12, 32-23, 76-13. In Approved Methods of the AACC; AACC: St. Paul, MN, 2000.

(28) Englyst, H. N.; Cummings, J. H. Simplified method for the measurement of total non-starch polysaccharides by gas-liquid chromatography of constituent sugars as alditol acetates. Analyst 1984, 109, 937-942.

(29) Loosveld, A. M. A.; Grobet, P. J.; Delcour, J. A. Contents and structural features of water-extractable arabinogalactan in wheat flour fractions. J. Agric. Food Chem. 1997, 45, 1998-2002.

(30) Pearce, K. N.; Kinsella, J. E. Emulsifying properties of proteinsEvaluation of a turbidimetric technique. J. Agric. Food Chem. 1978, 26, 716-723.

(31) van Koningsveld, G. A.; Walstra, P.; Gruppen, H.; Wijngaards, G.; van Boekel, M. A. J. S.; Voragen, A. G. J. Formation and stability of foam made with various potato protein preparations. J. Agric. Food Chem. 2002, 50, 7651-7659.

(32) Scopes, R. K. Protein Purification, Principles and Practice, 3rd ed.; Springer-Verlag: New York, 1993; p 380.

(33) Damodaran, S. Protein stabilization of emulsions and foams. J. Food Sci. 2005, 70, R54-R66.

Received February 23, 2009. Revised manuscript received April 30, 2009. The authors acknowledge the "Instituut voor de aanmoediging van Innovatie door Wetenschap en Technologie in Vlaanderen" (IWT, Brussels, Belgium) and Industrial Research Fund (Katholieke Universiteit Leuven, Leuven, Belgium) for financial support. 